\title{
Novel phenotypes of prediabetes?
}

\author{
Hans-Ulrich Häring ${ }^{1,2,3}$
}

Received: 27 January 2016 / Accepted: 16 May 2016/Published online: 25 June 2016

(C) The Author(s) 2016. This article is published with open access at Springerlink.com

\begin{abstract}
This article describes phenotypes observed in a prediabetic population (i.e. a population with increased risk for type 2 diabetes) from data collected at the University hospital of Tübingen. We discuss the impact of genetic variation on insulin secretion, in particular the effect on compensatory hypersecretion, and the incretin-resistant phenotype of carriers of the gene variant TCF $7 L 2$ is described. Imaging studies used to characterise subphenotypes of fat distribution, metabolically healthy obesity and metabolically unhealthy obesity are described. Also discussed are ectopic fat stores in liver and pancreas that determine the phenotype of metabolically healthy and unhealthy fatty liver and the recently recognised phenotype of fatty pancreas. The metabolic impact of perivascular adipose tissue and pancreatic fat is discussed. The role of hepatokines, particularly that of fetuin-A, in the crosstalk between these organs is described. Finally, the role of brain insulin resistance in the development of the different prediabetes phenotypes is discussed.
\end{abstract}

Keywords Brain insulin resistance · Insulin - Liver fat · Phenotype $\cdot$ Prediabetes $\cdot$ Review $\cdot$ Secretion $\cdot$ Sensitivity

Hans-Ulrich Häring

Hans-Ulrich.Haering@med.uni-tuebingen.de

1 Department of Internal Medicine IV, Division of Endocrinology, Diabetology, Angiology, Nephrology and Clinical Chemistry, University of Tübingen, Otfried-Müller-Str. 10, 72076 Tübingen, Germany

2 Institute of Diabetes Research and Metabolic Diseases (IDM), University of Tübingen, Tübingen, Germany

3 German Center for Diabetes Research (DZD), Neuherberg, Germany

\author{
Abbreviations \\ GI Glycaemic index \\ GLP-1 Glucagon-like peptide-1 \\ HSAT High saturated fat \\ IGT Impaired glucose tolerance \\ LSAT Restricted saturated fat \\ MCP-1 Monocyte chemoattractant protein-1 \\ MEG Magneto-encephalography \\ MHO Metabolically healthy obesity \\ MUHO Metabolically unhealthy obesity \\ NAFLD Non-alcoholic fatty liver disease \\ NGT Normal glucose tolerance \\ SNP Single-nucleotide polymorphism \\ TÜF Tübingen Family Study \\ TULIP Tübingen lifestyle intervention program
}

\section{Introduction}

The global increase in type 2 diabetes prevalence over recent decades puts a heavy health and socioeconomic burden on society. Lifestyle intervention with increased physical activity and a healthy diet is considered to be generally effective in preventing the development of diabetes [1-4]. Unfortunately, the prevention studies carried out so far have shown that a substantial number of prediabetic individuals (that is, those with increased risk for type 2 diabetes) seem to be non-responders to lifestyle interventions; the number needed to treat amounted to 7 in the Finnish Diabetes Prevention Study (DPS) and the US Diabetes Prevention Program (DPP) [1, 2]. Based on these studies and on pathophysiology-based studies in our population [5-7], it appears that even those individuals who are able to reduce their body fat mass adequately show a lack of improvement in hyperglycaemia and insulin resistance. To improve the 
efficacy of lifestyle intervention programmes, a precise understanding of the pathophysiology and the different phenotypes of the prediabetic population is needed.

There are several prediabetes cohorts throughout the world [8-13] that provide extensive information about the natural history of disease progression from a prediabetic state to overt type 2 diabetes. Eighteen years ago at the University Hospital of Tübingen we started to build up a similar cohort, which we named the Tübingen Family Study (TÜF). Currently, the cohort comprises more than 3000 individuals from whom we have obtained values for insulin sensitivity and insulin secretion. The distribution of insulin sensitivity and insulin secretion in our cohort (Fig. 1) largely reflects the results from other groups worldwide [8-13]. It is evident that people with high insulin sensitivity very seldom display disturbed glucose tolerance. At higher values of insulin resistance individuals remain glucose tolerant only if their pancreas is able to react with a compensatory hypersecretion of insulin. Partial compensatory hypersecretion characterises individuals within the range of impaired glucose tolerance, while people with the lowest values of insulin secretion often show overt type 2 diabetes. In about 400 participants of the TÜF study, we are now studying the acute and long-term effects on insulin resistance and secretion of a lifestyle intervention programme. We found that there was a significant improvement in insulin resistance after 1 year. However, in follow-up studies after 2 years and 8 years this benefit was not only lost but also, in contrast, increased insulin resistance developed over the years (H-U Häring, unpublished data). These findings are in agreement with those of other earlier studies [8-13]. The stepwise progression towards type 2 diabetes involves increasing insulin resistance, although it is well established that only when combined with a simultaneous loss of

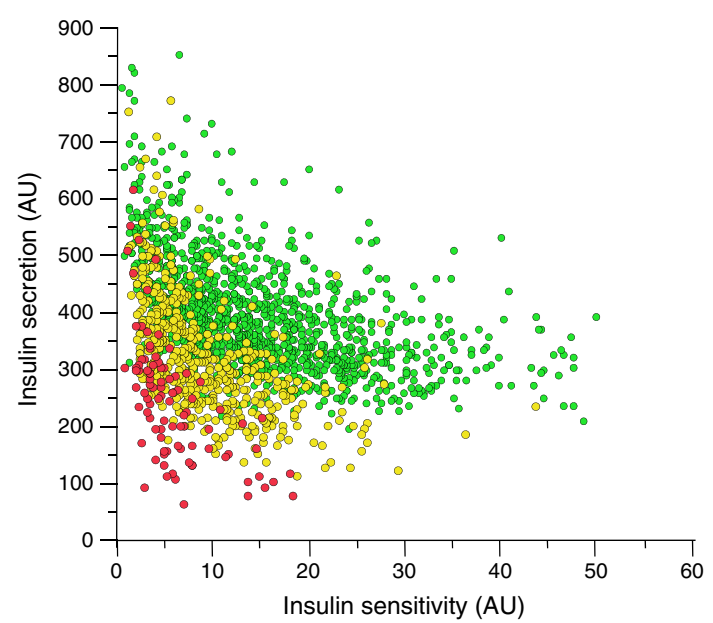

Fig. 1 Insulin sensitivity and insulin secretion of participants of the Tübingen Family Study. Insulin sensitivity is estimated from the OGTT (Matsuda-deFronzo index). Insulin secretion is estimated from the OGTT (AUC for C-peptide/glucose). Green circles, NGT; yellow circles, IGT; red circles, type 2 diabetes. AU, arbitrary units compensatory hypersecretion of insulin does this lead to diabetes [8-13]. The major questions are therefore: what pushes people from an insulin-sensitive status to one of insulin resistance and what underlies the ability of an individual to respond with compensatory insulin hypersecretion?

\section{Compensatory hypersecretion of insulin: influence of genetic variation}

Using our database, we assessed the extent to which genetic variation determines the ability to produce compensatory hypersecretion of insulin. A large number of type 2 diabetes loci are known today [14-16] and we studied genotypephenotype associations for the strongest type 2 diabetes genes [17-41].

We indeed found associations between many of the genetic variants and different features of insulin secretion [17-39]. Several of the gene variants showed interaction with other gene variants, and the degree of the effects was dependent on ligands that induce insulin secretion, such as incretins or fatty acids [17-25]. However, after quantifying the effect of these gene variants and testing for additive effects between variants and genotype-ligand interaction, it appears that the effects on insulin secretion are very small and often nonsignificant in insulin-sensitive individuals [30, 31]. In insulin-resistant individuals, who have higher insulin levels due to the compensatory effort of the pancreatic beta cell, the reduction in insulin secretion in association with these gene variants is more pronounced and significant [30, 31]. The quantitative effect, however, remains quite small, reaching only $15-20 \%$ of the compensatory response observed in individuals with normal glucose tolerance (NGT) vs impaired glucose tolerance (IGT) vs diabetes. This suggests that the type 2 diabetes genes known so far have only minor effects on insulin secretion and that variation in these genes does not contribute much to the large difference in compensatory hypersecretion of insulin that is seen when NGT, IGT and diabetic individuals are compared (Fig. 1).

TCF7L2 variants An exception to this picture emerges with genetic variants in $T C F 7 L 2$, a diabetes risk gene associated with incretin resistance [20]. Glucagon-like peptide-1 (GLP-1) infusion strongly induces insulin secretion in the experimental setting of a hyperglycaemic-euglycaemic clamp and this effect is clearly reduced in carriers of the TCF $2 L 2$ risk allele (Fig. 2a). When the glucose level increases, this gene variant seems to affect the ability of an individual to respond with a compensatory secretion of insulin [23] (Fig. 2b). Figure $2 \mathrm{~b}$ shows that individuals with the wild-type $\mathrm{C}$ allele of the rs7903146 single-nucleotide polymorphism (SNP) and individuals who are heterozygous for this SNP adequately respond to increasing glucose with increasing insulin 

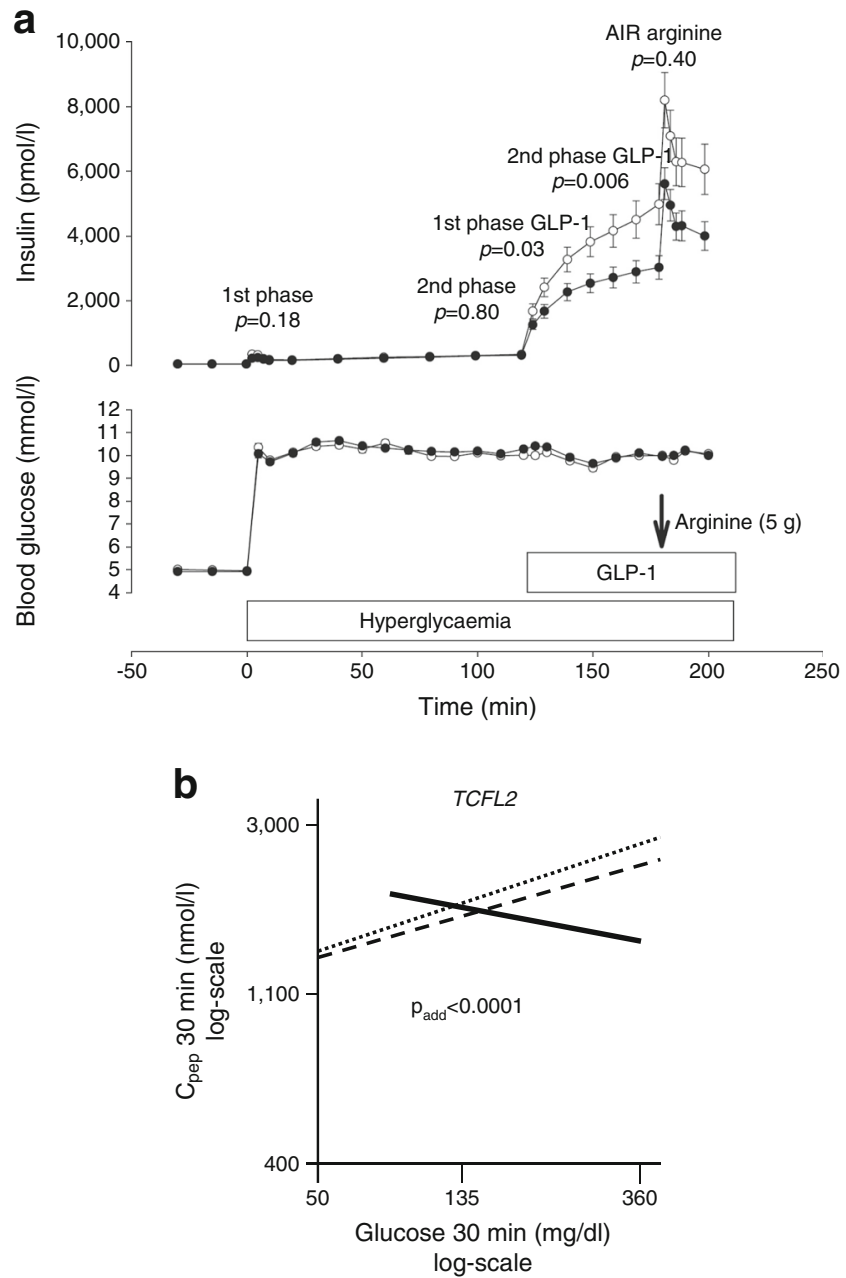

Fig. 2 (a) Associations between the genotypes of rs7903146 polymorphism in TCF7L2 with insulin secretion during a hyperglycaemic clamp in 73 German individuals. White circles, CC; black circles, CT and TT. AIR, acute insulin response. The $p$ values are for comparison between the genotypes for the first and second phases of glucose-induced insulin secretion, first and second phases of GLP-1-induced insulin secretion and acute insulin secretory response to arginine; figure reproduced with permission from [20]. (b) Association between C-peptide levels at $30 \mathrm{~min}$ of the OGTT and glucose levels at $30 \mathrm{~min}$ during the OGTT by TCF7L2 SNP rs7903146. Regression lines are shown. Dotted line, CC; dashed line, CT; solid line TT genotype of TCF7L2 SNP rs7903146; figure reproduced with permission from [23]. To convert glucose values from from $\mathrm{mg} / \mathrm{dl}$ to $\mathrm{mmol} / \mathrm{l}$, please multiply by 0.0555

secretion. In contrast, homozygous carriers of the T allele even show decreased insulin secretion at increasing glucose concentrations. This finding can be explained by reduced incretin signalling in these individuals [42].

This phenomenon has also been described by other groups [43-45]. A recent pharmacogenetic study showed that homozygous T allele carriers of the rs7903146 SNP of $T C F 7 L 2$ are partially resistant to therapy with dipeptidyl peptidase-4 (DPP-4) inhibitors, which are known to increase GLP-1 availability [46]. Approximately $10 \%$ of individuals in our database are homozygous carriers of this $\mathrm{T}$ allele, and the gene variant probably contributes to an inability to upregulate insulin secretion. It is important to note that a reduction in glucose levels through lifestyle intervention can reverse the reduced insulin secretion [23, 47]. Therefore, attempts to lower glucose levels both by lifestyle intervention and by pharmacotherapy might be able to slow down the disease progression in this subgroup of prediabetic individuals. Clinical studies to test this hypothesis are on the way. The role of this gene variant in glucose-induced insulin secretion and glucose metabolism has been addressed in many studies [48-51], some of which suggest that the gene variant affects glucose-induced insulin secretion and the conversion of proinsulin to insulin [38] as well as affecting glucose metabolism [50].

\section{Body fat composition}

Metabolically healthy and unhealthy obesity Studies using whole-body MRI not only allow identification of established metabolically relevant fat compartments [52] but also show new fat compartments like neck fat [53] and perivascular fat [54]. Furthermore, magnetic resonance spectroscopy technology allows determination of ectopic fat storage in the liver and the skeletal muscle [52]. A key observation made in such studies has been the description of subphenotypes of obesity: metabolically healthy obesity (MHO) and metabolically unhealthy obesity (MUHO) (Fig. 3).

We found that approximately $25 \%$ of the obese individuals in our cohort displayed a metabolically healthy phenotype [55-57]. These individuals predominantly accumulate less fat in the liver and store less fat in the visceral compartment, while fat storage in the subcutaneous compartment is high. Furthermore, they display high insulin sensitivity despite having a high BMI [58]. However, most of the obese individuals in our cohort had a metabolically unhealthy phenotype of fat distribution, characterised by decreased subcutaneous fat storage and increased fat storage in the visceral compartment and by non-alcoholic fatty liver disease (NAFLD) (Fig. 3). The insulin resistance of these individuals is associated with the amount of liver fat (Fig. 4a). However, it is evident that at each level of liver fat content a more-insulinresistant group can be distinguished from a less-insulinresistant group [57, 58] (Fig. 4a). We saw these data as evidence for distinct liver phenotypes - metabolically benign and metabolically malignant fatty liver [58].

Genetic predisposition A genetic predisposition seems to contribute to these phenotypes. Genome-wide association studies have identified a number of genetic variants for NAFLD [59]. The I148M variant of PNPLA3, the gene encoding patatin-like phospholipase domain-containing protein 3 , is most strongly associated with increased liver fat 
Fig. 3 Subphenotypes of obesity. Whole-body MRI measurements are used to quantify fat compartments [52-58].

(a) Yellow, subcutaneous adipose tissue; red, visceral adipose tissue. (b) pVAT, perivascular visceral adipose tissue a

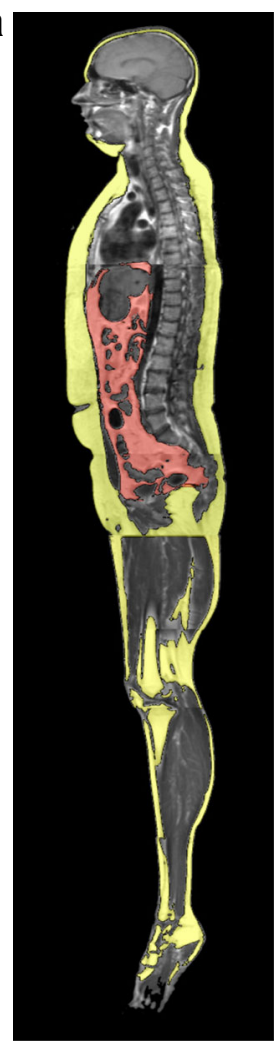

b

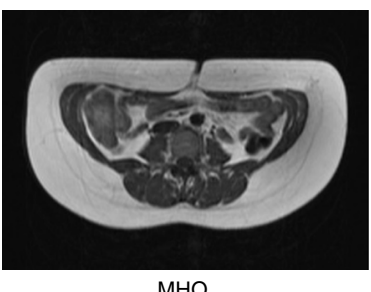

$\mathrm{MHO}$

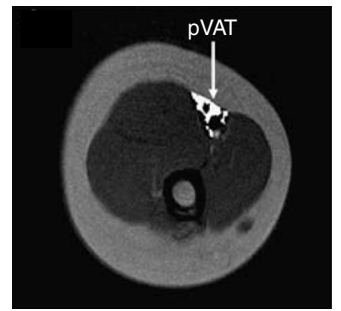

Low level of pVAT

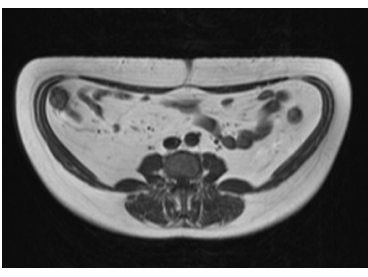

MUHO

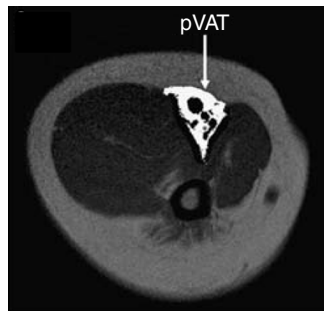

High level of pVAT
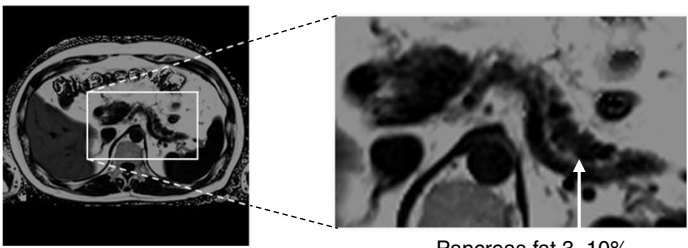

Pancreas fat $3-10 \%$

reticulum stress through AMP-activated protein kinase [70]. The exact mode of action of fetuin-A is still not fully understood.

George Grunberger's group was the first to show that fetuin-A inhibits signalling through the insulin receptor [71]) and we and others have confirmed fetuin-A's inhibitory effect on the insulin receptor tyrosine kinase [reviewed in 63, 64, 72]. Downstream effects on stress kinases and NFkB were observed [72].

Another signalling pathway that is modulated by fetuin-A is the fatty-acid signalling pathway, through the Toll-like receptor. Based on mouse data, it has been proposed that fetuin-A acts as an endogenous ligand of Toll-like receptor 4 to promote lipid-induced insulin resistance [73]. This concept seems to be relevant in humans, as we were able to show that, indeed, circulating fetuin-A levels and NEFA interacted to predict insulin resistance in participants of the TÜF study [64]. These data support the concept that organ crosstalk through hepatokines plays a key role in the pathophysiology of prediabetes.

\section{Perivascular adipose tissue}

Perivascular fat cells seem to be a particularly important target of hepatokines, which might function as transducers of organ

HepG2 cells by improving palmitate-induced endoplasmic 

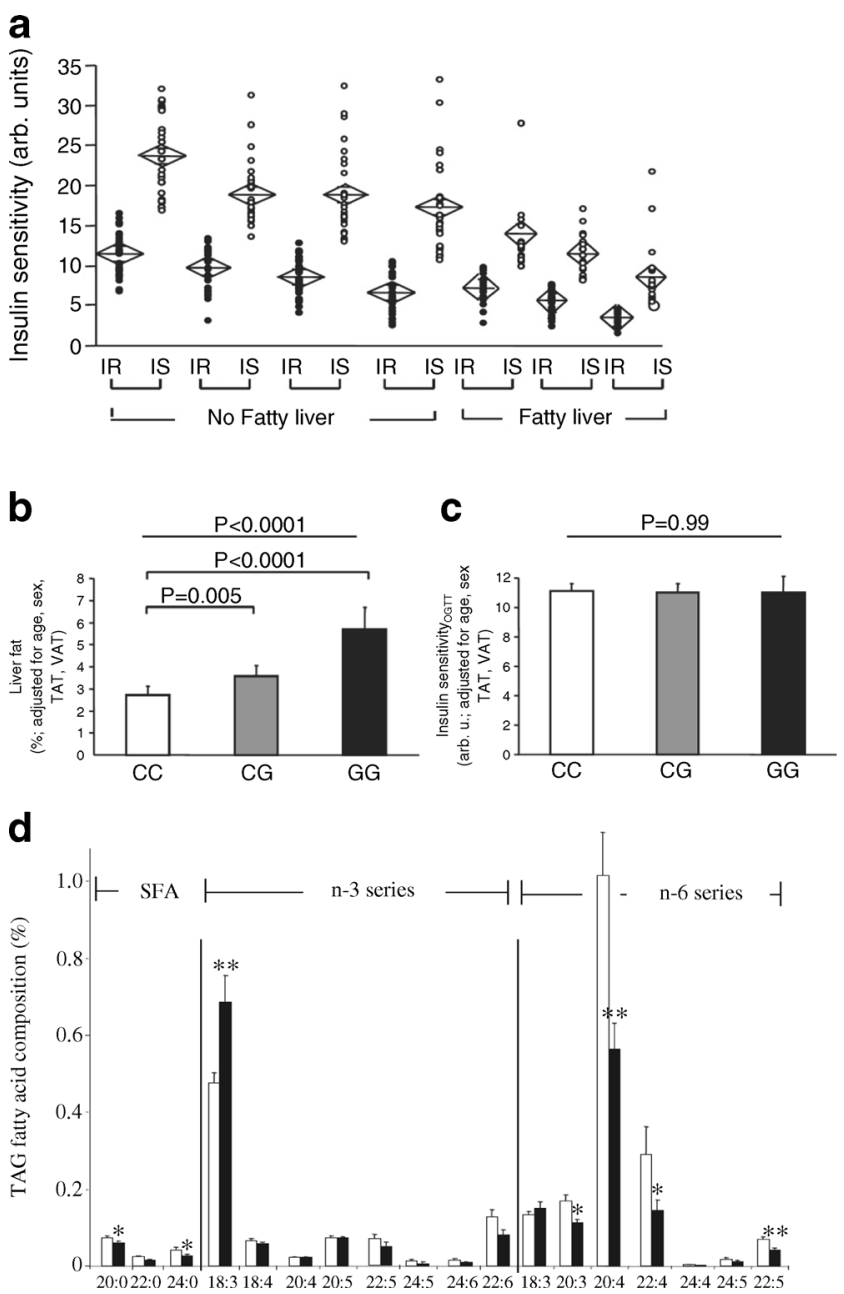

Fig. 4 (a) Association of insulin resistance with the amount of liver fat. Individuals were divided into seven groups: quartiles of liver fat in individuals without fatty liver (liver fat $<5.56 \%, n=225$ ) and tertiles of liver fat in individuals with fatty liver (liver fat $\geq 5.56 \%, n=112$ ). Each group was then divided by the median insulin sensitivity into an insulin-sensitive (IS, white circles) and an insulin-resistant (IR, black circles) subgroup. Diamonds indicate mean and the $95 \%$ CI. Within each of the seven groups, the subgroups did not differ in liver fat. However, insulin sensitivity was lower in each group; figure reproduced with permission from [58]. (b, c) Liver fat content (b) and insulin sensitivity (c) associated with the I148M variant of PNPLA3,; figure reproduced with permission from [60]. (d) Fatty-acid profiles of hepatic triacylglycerol stores are dependent on the I148M variant of PNPLA3. White bars, wild-type individuals; black bars, PNPLA3 $3^{\mathrm{I1} 48 \mathrm{M}}$ individuals; figure reproduced with permission from [61]. TAG, triacylglycerol; TAT, total adipose tissue; VAT, visceral adipose tissue

crosstalk [54, 74-78]. The whole-body MRI data led us to study another interesting fat compartment - perivascular adipose tissue (Fig. 3). Perivascular adipose tissue is a specific fat depot with impact on organ functions [54, 74-78]. The adipose tissue surrounding arteries seems to have an influence on whole-body insulin sensitivity. This effect is independent of other fat compartments like hepatic fat and visceral fat [54]. Due to the strong effect on whole-body insulin sensitivity, we hypothesised that perivascular adipocytes would have specific characteristics that distinguish them from visceral or subcutaneous fat cells. This is indeed the case, as perivascular fat cells produce and secrete higher quantities of angiogenic factors, cytokines and chemoattractants like monocyte chemoattractant protein-1 (MCP-1) [76]. Furthermore, these fat cells seem to be particularly susceptible to organ crosstalk signals from the fatty liver [72]. The hepatokine fetuin-A stimulates, together with fatty acids, cytokine release and MCP-1 expression in these cells [72].

Fat cells are also found around the renal artery in the hilus of the kidney. As the amount of kidney fat in the hilus correlates with hypertension-inducible albuminuria in individuals with prediabetes $[77,78]$, we speculate that this fat compartment might be relevant in the pathogenesis of diabetic kidney disease. We further observed that these renal fat cells are particularly responsive to crosstalk signals from the fatty liver (i. e. fetuin-A). Thus, the fatty kidney might be a subphenotype of prediabetes that defines a higher risk of developing kidney disease in the context of MUHO and NAFLD. This is of course at the moment a pure speculation that has to be tested in prospective studies.

\section{The fatty pancreas: non-alcoholic fatty pancreas disease}

Ectopic fat storage is also observed in the pancreas. In MRI studies, about $3-10 \%$ of fat is detected in the pancreas (Fig. 3). The pancreatic fat content does not correlate with insulin secretion in individuals with NGT, although it does correlate strongly with insulin secretion in individuals with IGT [79]. We recently demonstrated that these magnetic resonancederived fat signals reflect clusters of fat cells in the pancreas, found in close vicinity to islets and sometimes even within islets (Fig. 5a). Macrophages were also detectable. We speculate that fat cells, islets and macrophages are engaged in a cell-to-cell crosstalk (Fig. 5e), which alters the expression of chemoattractants and cytokines. It is likely that this process modifies lipolysis of fat cells and, thereby, fatty-acid signalling. This cell crosstalk is probably silent in the situation of normal glycaemia, while in IGT additional stimulators are present, most likely glucose, cytokines, adipokines and hepatokines. In this respect, we could show that insulin secretion is correlated to the level of circulating fetuin-A in individuals with IGT [80]. Based on this data, we favour the following concept of organ crosstalk in prediabetes: MUHO might induce the development of fatty liver and organ crosstalk, which involves fetuin-A; in the presence of a fatty pancreas, this hepatokine could amplify the cellular crosstalk described in Fig. 5 and this might finally affect islet function and survival and therefore the capacity for compensatory insulin hypersecretion. 
a
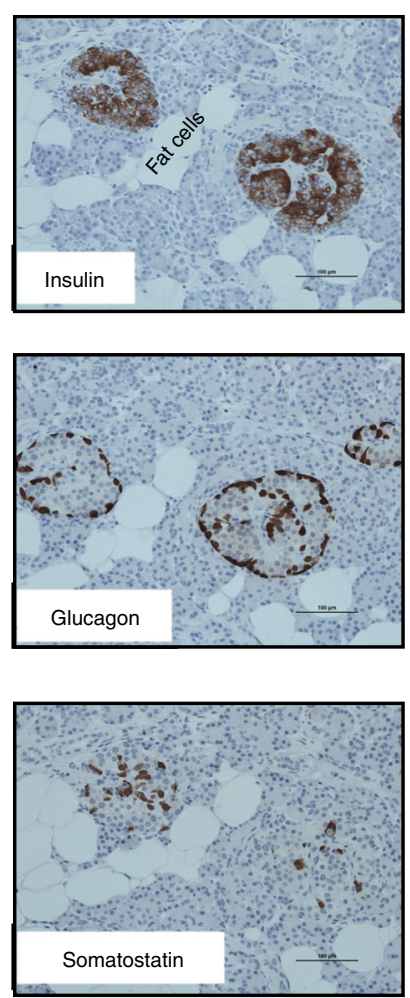

b

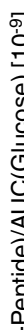

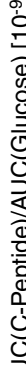
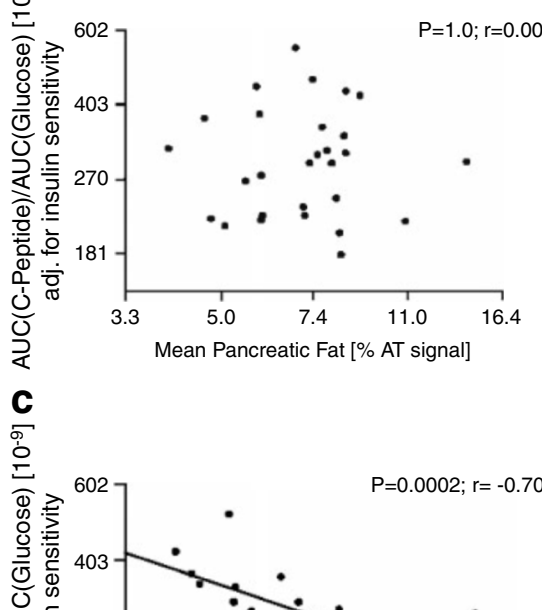

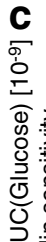

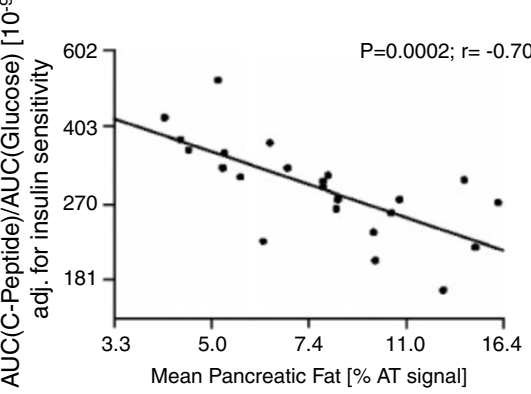

d

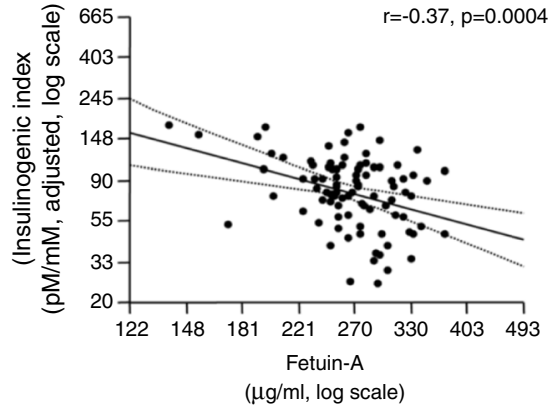

e

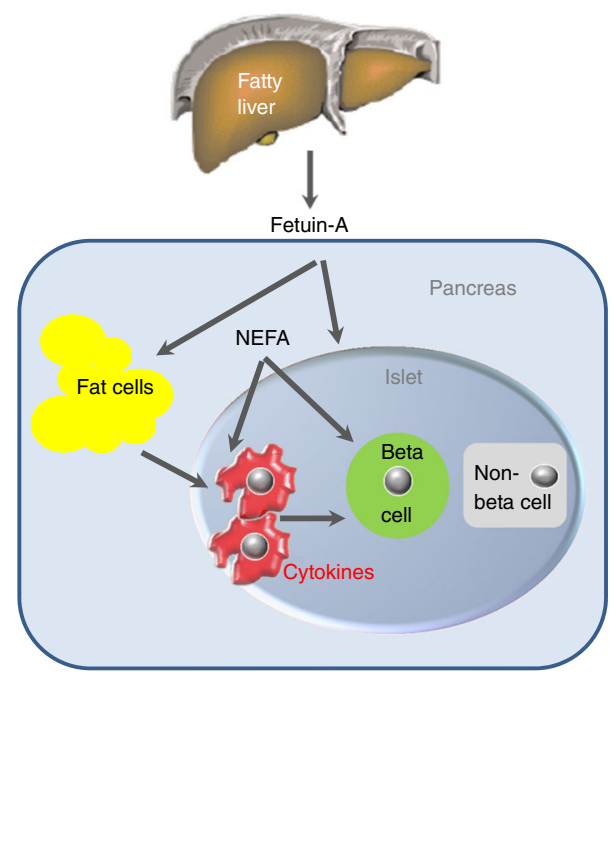

(d) Association of increased fetuin-A from fatty liver with impaired insulin secretion; figure reproduced from [80]. (e) Cell-to-cell crosstalk between intrapancreatic fat cells, islets and macrophages

\section{Response to lifestyle intervention}

All these observations support a key role for NAFLD in the pathogenesis of insulin resistance and the progression from NGT to IGT and finally to type 2 diabetes. Furthermore, our lifestyle intervention study has clearly shown that lifestyle intervention has limited success in improving glycaemia in prediabetic individuals who have NAFLD [7]. Therefore, other approaches to reduce liver fat content are extremely important.

Dietary intervention is a powerful tool with which to reduce liver fat [81-86]. However, there is evidence that the susceptibility to carbohydrate-dependent induction of liver fat shows a large inter-individual variation [81], suggesting the existence of diet non-responders. A study in patients with biopsy-proven NAFLD showed that a 2 week administration of a very-low-carbohydrate diet ( $20 \mathrm{~g} /$ day) vs energy restriction (5000-6300 kJ/day) reduced hepatic triacylglycerol levels by a greater amount ( $-55 \%$ vs $-28 \%$, respectively), while weight loss was similar in both groups $(-4.0 \mathrm{~kg}$ vs $-4.6 \mathrm{~kg}$ ) [82].

In another study carried out over 16 weeks in 52 individuals with obesity, insulin resistance and suspected NAFLD, a normal carbohydrate $(60 \%$ carbohydrate, $25 \%$ fat, $15 \%$ protein) or moderately restricted carbohydrate $(40 \%$ carbohydrate, $45 \%$ fat, $15 \%$ protein) diet again resulted in a similar decrease in body weight, daily insulin requirement and plasma liver enzymes levels. However, the moderately restricted carbohydrate intervention was associated with a larger decrease in insulin resistance and liver enzymes [83].

The effect of an isoenergetic diet with restricted fat, restricted saturated fat (LSAT) and restricted glycaemic index 
(GI) (LSAT: $23 \%$ fat [7\% saturated fat], GI < 55) on liver fat content was compared with the effect of a high-fat, highsaturated fat (HSAT) and high-GI (HSAT: 43\% fat [24\% saturated fat] GI > 70) diet in an elderly population. In the LSAT group, but not in the HSAT group, liver fat content decreased significantly [84].

In most studies intake of n-3 polyunsaturated fatty-acid supplements is associated with a reduction in liver fat content, with the doses ranging from 0.83 to $6 \mathrm{~g}$ /day, and duration of therapy ranging from 8 weeks to 18 months $[85,86]$.

The microbiome is probably important as well, although targeted interventions are not feasible as yet.

\section{The phenotype of non-response to exercise}

From our own experience in the Tübingen lifestyle intervention program (TULIP) study, we suggest that effective reduction of liver fat content during lifestyle intervention is very much related to physical fitness and to variants in the genes for the adiponectin receptor $A D I P O R 1$ [87] and the transcription factor $P P A R \delta$ (also known as PPARD) $[6,88]$ (Fig. 6).

Exercise is a key factor in influencing metabolism [89, 90] and reducing liver fat content [91]. However, response to exercise is highly variable. Studies by different groups [90-98; for review see 92] have shown that a certain proportion of prediabetic individuals does not adequately respond to exercise, with respect to fitness variables, like $\dot{V} \mathrm{O}_{2 \max }$ and lactate threshold, and insulin sensitivity. We have made the same observation in our lifestyle intervention study (Fig. 7). Understanding the cause of exercise non-response is crucial for improving the success of a lifestyle intervention. We have performed controlled exercise studies in responders and non-responders and have used muscle biopsies to study the underlying molecular mechanisms. It appears that

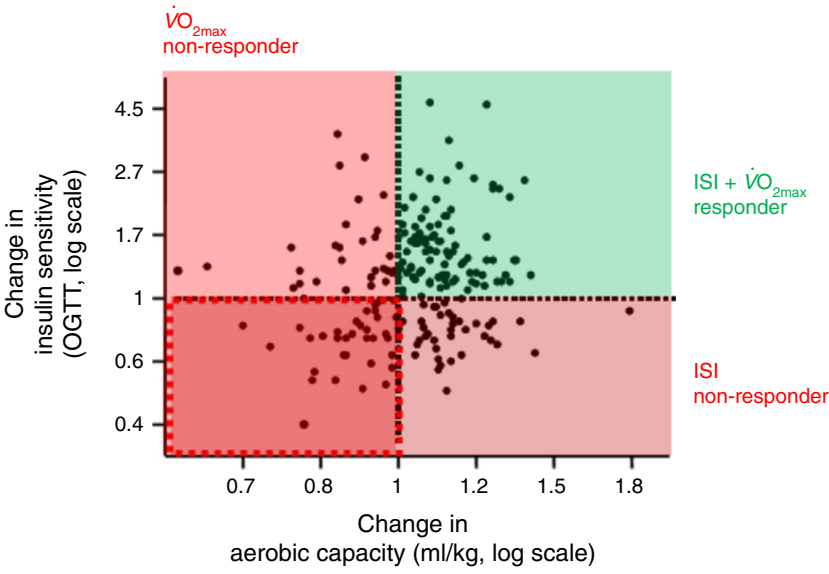

Fig. 7 Change in aerobic capacity plotted against change in insulin sensitivity during lifestyle intervention. ISI, Insulin Sensitivity Index calculated from OGTT

differences in the transcriptional response of muscle cells of the responders and non-responders might explain the different phenotypes as well as differences in the exercise-induced release of myokines [96-98].

As a consequence, differences in the adaptation of fuel oxidation are potentially responsible for these phenotypes.

\section{Insulin action in the human brain: the phenotype of brain insulin resistance}

For a long time the brain was not considered to be a classical target organ of insulin action. However, as early as 1978, Roth and colleagues showed that mouse and rat brain express high levels of insulin receptors [99, 100]. Later, around 2000, several groups showed that alteration of the insulin signalling chain in the brain by knockdown of the insulin receptor or docking proteins causes brain insulin resistance, leading to a diabetes-like phenotype in mice [101-103].

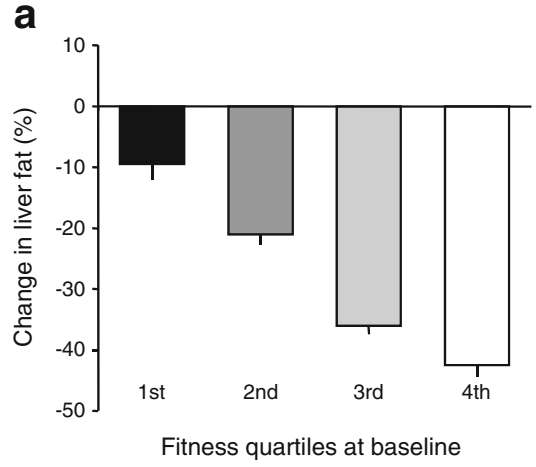

Fig. 6 Reduction of liver fat content during a lifestyle intervention is very much related to physical fitness at baseline $(p=0.004)$ (a) and to genetic factors $(\mathbf{b}, \mathbf{c})$. Genetic variation in transcription factor PPAR $\delta$ : black bar, carriers of the risk allele; white bar, non-carriers of the risk
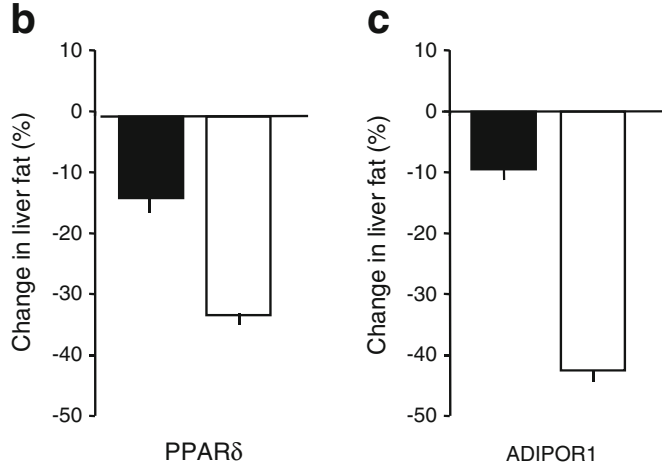

allele $(p=0.001)$. Genetic variation in the receptor for adiponectin ADIPOR1: black bar, carriers of the risk allele; white bar, non-carriers of the risk allele $(p=0.004)$. Error bars are SEM. Figures plotted using data from [91] (a), [88] (b) and [87] (c) 
For technical reasons it is difficult to demonstrate brain insulin action in humans. We used magnetoencephalography (MEG) to examine insulin effects under the condition of a euglycaemic-hyperinsulinaemic clamp and showed that insulin infusion induces a strong MEG signal in lean individuals but not in obese individuals [104]. We interpreted this as a sign of brain insulin resistance in obese people. In many subsequent studies using functional MRI (fMRI) we further characterised insulin action in the human brain and identified the major insulin-sensitive areas. We have recently reviewed these studies and therein discussed the causes and consequences of brain insulin resistance [105]. Brain insulin signals are detected in the hypothalamus, frontal areas, hippocampus and fusiform gyrus and modulate behavioural functions. We have shown that brain insulin resistance affects very specifically the interaction of the hypothalamus with frontal areas and is associated with insulin sensitivity and amount of visceral fat (Fig. 8) [106]. Very recently, we also showed that brain insulin signalling affects peripheral glucose metabolism [107]. In clamp studies using submaximally active peripheral insulin concentrations, the application of nasal insulin produced an additional increase of glucose uptake in the periphery. Nasal insulin is an efficient tool with which to directly stimulate the human brain [107-111]. This effect of intranasal insulin is closely associated with insulin-dependent activation of the hypothalamus and seems to be transmitted through the autonomous nervous system.

\section{Brain insulin sensitivity: cause or consequence of adipose tissue distribution?}

In our lifestyle intervention study (TULIP) we investigated whether the response to lifestyle intervention is related to brain insulin sensitivity. We found that brain insulin sensitivity was closely related to the change in visceral adipose tissue during lifestyle intervention (Fig. 9) [112]. A potential explanation for this observation might involve autonomous nervous signalling induced by brain insulin action which controls visceral adipose tissue storage. High hypothalamic brain insulin sensitivity associates with increased subcutaneous fat and decreased visceral fat. Low hypothalamic brain insulin sensitivity correlates with high visceral fat and low subcutaneous fat (Fig. 8). This suggests that brain insulin resistance might contribute to the phenotype of MUHO. MHO might depend on strong hypothalamic brain insulin signalling. However, this concept is still very speculative and future studies need to discover whether this hypothesis is valid. While proof from human data is still lacking, several animal models suggest that there is an interaction between brain insulin signalling and the described phenotypes, in particular for fatty liver [113-116]. In accordance with these
Fig. 8 Insulin-sensitive regions in the human brain.

(a) Hypothalamus. (b) Prefrontal area. Data from studies with intranasal insulin application. Figure modified with permission from [106]. CBF, cerebral blood flow; VAT, visceral adipose tissue
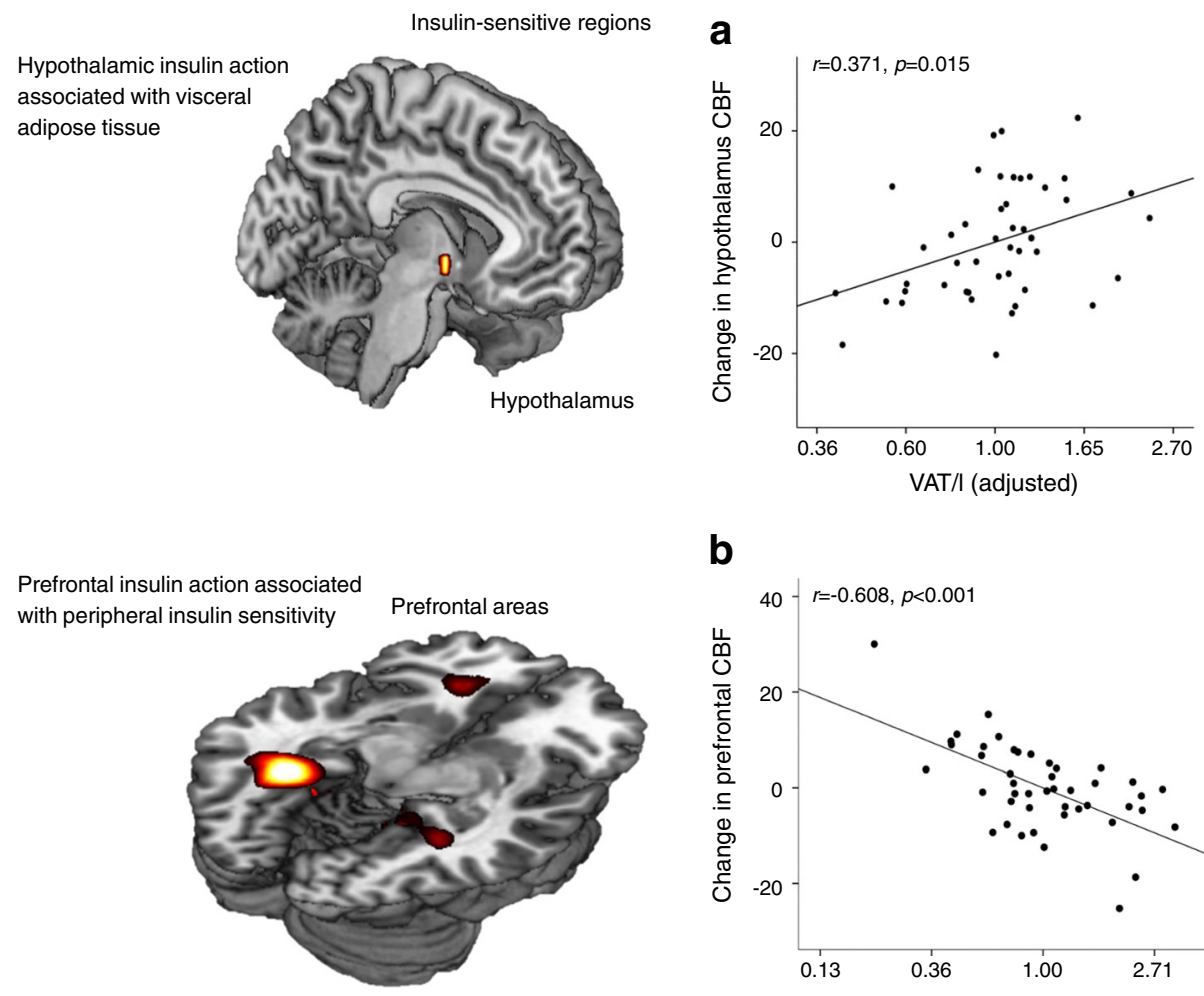

b

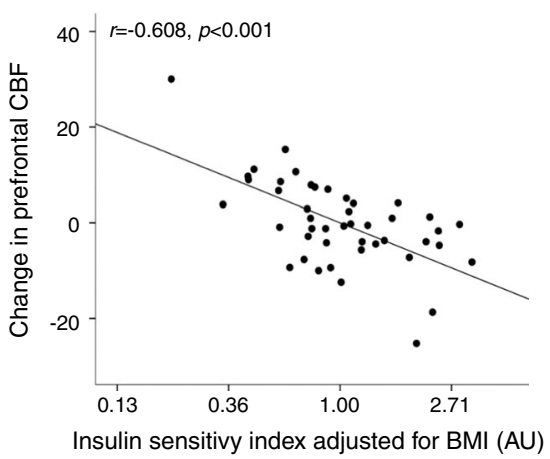


Fig. 9 (a) Diagrams illustrating the investigation of visceral adipose tissue with magnetic resonance imaging (MRI) and the measurement of cerebral insulin sensitivity using the technique of magnetoencephalography (MEG). (b) Brain insulin sensitivity before lifestyle intervention (as insulinstimulated theta activity) and its association with the change in visceral adipose tissue (adjusted for baseline) during lifestyle intervention; $r=-0.76 ; p=0.001$; figure reproduced with permission from [112]. VAT, visceral adipose tissue a

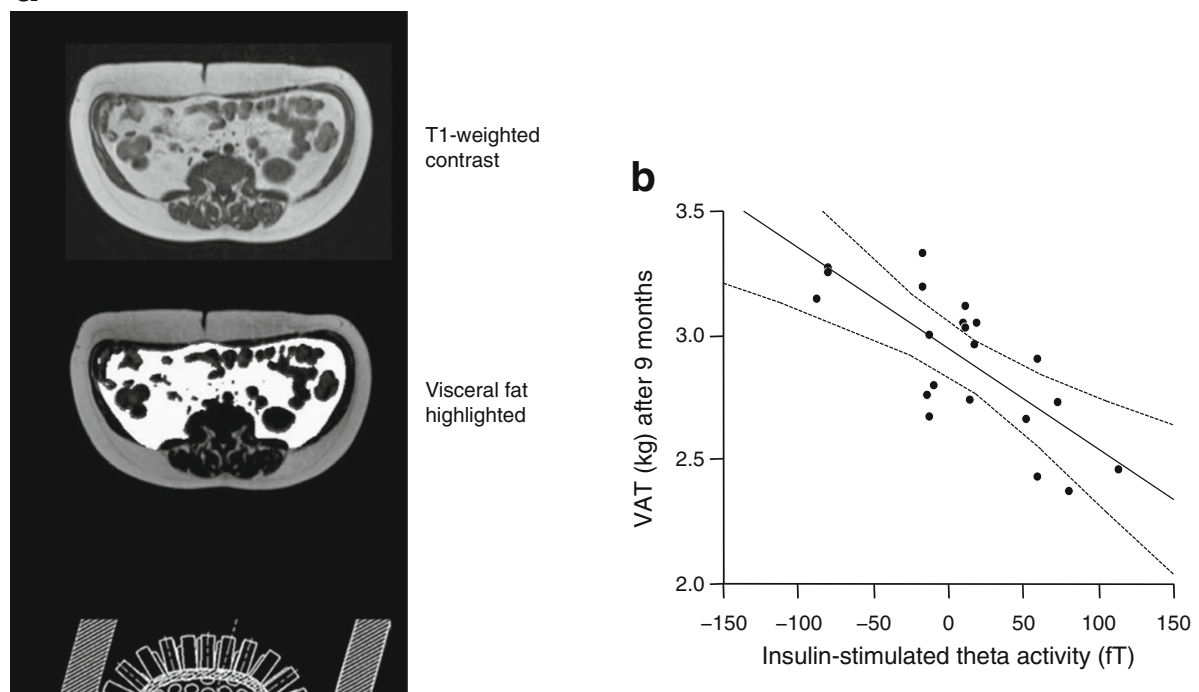

animal data it has recently been shown that nasal insulin alters fuel flux in the liver in humans [117]. In as yet unpublished studies (M. Heni and A. Fritsche) we recently showed, with the use of stable isotopes, that nasal insulin affects substrate distribution between liver and peripheral tissues. Thus, a crucial role for brain insulin signalling in body fat distribution seems likely.

\section{Effects of gestational diabetes on fetal brain: does primary brain insulin resistance exist?}

Brain insulin resistance can already be found in young obese people [106-111]. This observation allows one to speculate that brain insulin resistance might indeed precede the development of obesity. To further test this hypothesis we studied fetal brain development in pregnancies of insulin-sensitive mothers, insulin-resistant mothers and mothers with gestational diabetes [118, 119]. Fetal brain functions were tested by fetal MEG (fMEG) and the findings suggested that indeed the metabolic situation of the mothers might influence fetal brain insulin sensitivity. It seems therefore conceivable that brain insulin resistance is induced already in utero. Further studies are required to show whether this leads to altered behaviour, altered eating habits and altered weight gain in the postnatal life of these children.

Fig. 10 Concept of the pathogenesis of type 2 diabetes mellitus. Chronological development of disadvantageous organ crosstalk involved in the progression from NGT to the prediabetic situation and to type 2 diabetes

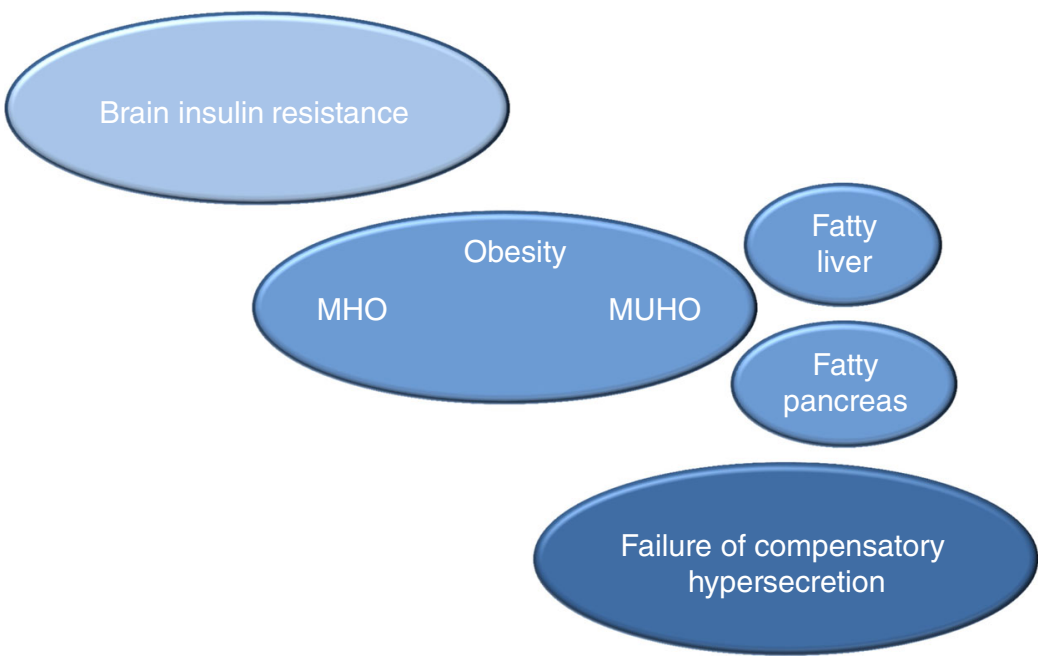




\section{Brain insulin resistance: starting point for organ crosstalk defining prediabetic phenotypes?}

Major phenotypes of prediabetic individuals include brain insulin resistance, subphenotypes of obesity (MHO and MUHO), fatty liver, fatty pancreas and variations in perivascular fat. At the level of the pancreas both compensatory insulin hypersecretion and beta cell dysfunction are observed. We speculate that the chronological development of the organ crosstalk is a key feature of the progression from NGT to the prediabetic situation and to type 2 diabetes. Figure 10 illustrates this speculative concept. Brain insulin resistance might occur very early in life and may be the first event contributing to an unfavourable fat distribution pattern (increased visceral fat). MUHO might then be a stepping stone to the development of fatty liver. Hepatokines provide the communication with other organs. Fat cells from perivascular tissue, perihilar fat of the kidney and fat cells in the pancreas seem to be particularly responsive to combined signals of saturated fatty acids and fetuin. These fat cells respond with a pattern of inflammation that probably activates macrophages. The fatty liver might, through these mechanisms, influence both key pathomechanisms of prediabetes, namely insulin resistance and inability to produce compensatory insulin hypersecretion. This scenario is of course very speculative at present but it might be useful as a roadmap for further studies aimed at understanding the chronology underlying the pathophysiology of prediabetes development.

Acknowledgements I wish to thank all my collaborators from the University Hospital and the University of Tübingen, Germany for their consistent support over many years. I am particularly grateful to N. Birbaumer, C. D. Claussen, A. Fritsche, B. Gallwitz, F. Gerst, M. Heni, M. Hrabe de Angelis, A. Königsrainer, S. Kullmann, R. Lehmann, J. Machann, F. Machicao, A. Peter, H. Preiß1, K. Rittig, N. Stefan, F. Schick, E. Schleicher, D. Siegel-Axel, H. Staiger, S. Ullrich and C. Weigert.

Duality of interest The author declares that there is no duality of interest associated with this manuscript.

Contribution statement The author was the sole contributor to this paper.

Open Access This article is distributed under the terms of the Creative Commons Attribution 4.0 International License (http:// creativecommons.org/licenses/by/4.0/), which permits unrestricted use, distribution, and reproduction in any medium, provided you give appropriate credit to the original author(s) and the source, provide a link to the Creative Commons license, and indicate if changes were made.

\section{References}

1. Tuomilehto J, Lindström J, Eriksson JG et al (2001) Prevention of type 2 diabetes mellitus by changes in lifestyle among subjects with impaired glucose tolerance. N Engl J Med 344:1343-1350
2. Knowler WC, Barrett-Connor E et al (2002) Reduction in the incidence of type 2 diabetes with lifestyle intervention or metformin. N Engl J Med 346:393-403

3. Li G, Zhang P, Wang J et al (2008) The long-term effect of lifestyle interventions to prevent diabetes in the China Da Qing Diabetes Prevention Study: a 20-year follow-up study. Lancet 371: 1783-1789

4. Perreault L, Pan Q, Mather KJ et al (2012) Effect of regression from prediabetes to normal glucose regulation on long-term reduction in diabetes risk: results from the Diabetes Prevention Program Outcomes Study. Lancet 379:2243-2251

5. Thamer C, Machann J, Stefan N et al (2007) High visceral fat mass and high liver fat are associated with resistance to lifestyle intervention. Obesity (Silver Spring) 15:531-538

6. Stefan N, Thamer C, Staiger $\mathrm{H}$ et al (2007) Genetic variations in PPARD and PPARGC1A determine mitochondrial function and change in aerobic physical fitness and insulin sensitivity during lifestyle intervention. J Clin Endocrinol Metab 92:1827-1833

7. Stefan N, Staiger H, Wagner R et al (2015) A high-risk phenotype associates with reduced improvement in glycaemia during a lifestyle intervention in prediabetes. Diabetologia 58:2877-2884

8. Weyer C, Bogardus C, Mott DM, Pratley RE (1999) The natural history of insulin secretory dysfunction and insulin resistance in the pathogenesis of type 2 diabetes mellitus. J Clin Invest 104: 787-794

9. Ferrannini E (2014) Definition of intervention points in prediabetes. Lancet Diabetes Endocrinol 2:667-675

10. Kahn SE, Hull RL, Utzschneider KM (2006) Mechanisms linking obesity to insulin resistance and type 2 diabetes. Nature 444: 840-846

11. Bergman RN, Ader M, Huecking K, Van Citters G (2002) Accurate assessment of beta-cell function: the hyperbolic correction. Diabetes 51(Suppl 1):S212-S220

12. Stancáková A, Javorský M, Kuulasmaa T, Haffner SM, Kuusisto J, Laakso M (2009) Changes in insulin sensitivity and insulin release in relation to glycemia and glucose tolerance in 6,414 Finnish men. Diabetes 58:1212-1221

13. Eriksson J, Franssila-Kallunki A, Ekstrand A et al (1989) Early metabolic defects in persons at increased risk for non-insulindependent diabetes mellitus. N Engl J Med 321:337-343

14. Lyssenko V, Jonsson A, Almgren P et al (2008) Clinical risk factors, DNA variants, and the development of type 2 diabetes. N Engl J Med 359:2220-2232

15. Mohlke KL, Boehnke M (2015) Recent advances in understanding the genetic architecture of type 2 diabetes. Hum Mol Genet 24:R85-R92

16. DIAbetes Genetics Replication and Meta-analysis (DIAGRAM) Consortium, Asian Genetic Epidemiology Network Type 2 Diabetes (AGEN-T2D) Consortium, South Asian Type 2 Diabetes (SAT2D) Consortium et al (2014) Genome-wide trans-ancestry meta-analysis provides insight into the genetic architecture of type 2 diabetes susceptibility. Nat Genet 46:234-244

17. Wagner R, Hieronimus A, Lamprinou A et al (2014) Peroxisome proliferator-activated receptor gamma (PPARG) modulates free fatty acid receptor 1 (FFAR1) dependent insulin secretion in humans. Mol Metab 3:676-680

18. Wagner R, Staiger H, Ullrich S, Stefan N, Fritsche A, Häring HU (2014) Untangling the interplay of genetic and metabolic influences on beta-cell function: examples of potential therapeutic implications involving TCF7L2 and FFAR1. Mol Metab 3: 261-267

19. Ordelheide AM, Gerst F, Rothfuss O et al (2013) Nor-1, a novel incretin-responsive regulator of insulin genes and insulin secretion. Mol Metab 2:243-255 
20. Schäfer SA, Tschritter O, Machicao F et al (2007) Impaired glucagon-like peptide-1-induced insulin secretion in carriers of transcription factor 7-like 2 (TCF7L2) gene polymorphisms. Diabetologia 50:2443-2450

21. Schäfer SA, Müssig K, Staiger H et al (2009) A common genetic variant in WFS1 determines impaired glucagon-like peptide1-induced insulin secretion. Diabetologia 52:1075-1082

22. Müssig K, Staiger H, Machicao F et al (2009) Association of type 2 diabetes candidate polymorphisms in KCNQ1 with incretin and insulin secretion. Diabetes 58:1715-1720

23. Heni M, Ketterer C, Thamer C et al (2010) Glycemia determines the effect of type 2 diabetes risk genes on insulin secretion. Diabetes 59:3247-3252

24. Stefan N, Fritsche A, Häring H, Stumvoll M (2001) Effect of experimental elevation of free fatty acids on insulin secretion and insulin sensitivity in healthy carriers of the Pro12Ala polymorphism of the peroxisome proliferator-activated receptor-gamma2 gene. Diabetes 50:1143-1148

25. Wagner R, Kaiser G, Gerst F et al (2013) Reevaluation of fatty acid receptor 1 (FFAR1/GPR40) as drug target for the stimulation of insulin secretion in humans. Diabetes 62:2106-2111

26. Wagner R, Li J, Kenar E et al (2014) Clinical and non-targeted metabolomic profiling of homozygous carriers of transcription factor 7-like 2 variant rs7903146. Sci Rep 4:5296

27. Hribal ML, Presta I, Procopio T et al (2011) Glucose tolerance, insulin sensitivity and insulin release in European non-diabetic carriers of a polymorphism upstream of $C D K N 2 A$ and CDKN2B. Diabetologia 54:795-802

28. Wagner R, Dudziak K, Herzberg-Schäfer SA et al (2011) Glucoseraising genetic variants in $M A D D$ and $A D C Y 5$ impair conversion of proinsulin to insulin. PLoS One 6, e23639

29. 't Hart LM, Simonis-Bik AM, Nijpels G et al (2010) Combined risk allele score of eight type 2 diabetes genes is associated with reduced first-phase glucose-stimulated insulin secretion during hyperglycemic clamps. Diabetes 59:287-292

30. Haupt A, Guthoff M, Schäfer SA et al (2009) The inhibitory effect of recent type 2 diabetes risk loci on insulin secretion is modulated by insulin sensitivity. J Clin Endocrinol Metab 94:1775-1780

31. Haupt A, Staiger H, Schäfer SA et al (2009) The risk allele load accelerates the age-dependent decline in beta cell function. Diabetologia 52:457-462

32. Groenewoud MJ, Dekker JM, Fritsche A et al (2008) Variants of $C D K A L 1$ and IGF2BP2 affect first-phase insulin secretion during hyperglycaemic clamps. Diabetologia 51:1659-1663

33. Boesgaard TW, Zilinskaite J, Vänttinen M et al (2008) The common SLC30A8 Arg325Trp variant is associated with reduced first-phase insulin release in 846 non-diabetic offspring of type 2 diabetes patients - the EUGENE2 study. Diabetologia 51: $816-820$

34. Staiger H, Stancáková A, Zilinskaite J et al (2008) A candidate type 2 diabetes polymorphism near the HHEX locus affects acute glucose-stimulated insulin release in European populations: results from the EUGENE2 study. Diabetes 57:514-517

35. Stancáková A, Pihlajamäki J, Kuusisto J et al (2008) Singlenucleotide polymorphism rs7754840 of CDKAL1 is associated with impaired insulin secretion in nondiabetic offspring of type 2 diabetic subjects and in a large sample of men with normal glucose tolerance. J Clin Endocrinol Metab 93:1924-1930

36. Staiger H, Machicao F, Schäfer SA et al (2008) Polymorphisms within the novel type 2 diabetes risk locus MTNRIB determine beta-cell function. PLoS One 3, e3962

37. Staiger H, Machicao F, Kantartzis K et al (2008) Novel metaanalysis-derived type 2 diabetes risk loci do not determine prediabetic phenotypes. PLoS One 3, e3019
38. Kirchhoff K, Machicao F, Haupt A et al (2008) Polymorphisms in the TCF7L2, CDKAL1 and SLC30A8 genes are associated with impaired proinsulin conversion. Diabetologia 51:597-601

39. Staiger H, Machicao F, Stefan N et al (2007) Polymorphisms within novel risk loci for type 2 diabetes determine beta-cell function. PLoS One 2, e832

40. Haupt A, Thamer C, Heni M et al (2010) Gene variants of TCF7L2 influence weight loss and body composition during lifestyle intervention in a population at risk for type 2 diabetes. Diabetes 59:747-750

41. Heni M, Herzberg-Schäfer S, Machicao F, Häring HU, Fritsche A (2012) Dietary fiber intake modulates the association between variants in TCF7L2 and weight loss during a lifestyle intervention. Diabetes Care 35, e24

42. Shu L, Sauter NS, Schulthess FT, Matveyenko AV, Oberholzer J, Maedler K (2008) Transcription factor 7-like 2 regulates beta-cell survival and function in human pancreatic islets. Diabetes 57: 645-653

43. Pilgaard K, Jensen CB, Schou JH et al (2009) The T allele of rs7903146 TCF7L2 is associated with impaired insulinotropic action of incretin hormones, reduced $24 \mathrm{~h}$ profiles of plasma insulin and glucagon, and increased hepatic glucose production in young healthy men. Diabetologia 52:1298-1307

44. Villareal DT, Robertson H, Bell GI et al (2010) TCF7L2 variant rs7903146 affects the risk of type 2 diabetes by modulating incretin action. Diabetes 59:479-485

45. Lyssenko V, Lupi R, Marchetti P et al (2007) Mechanisms by which common variants in the TCF7L2 gene increase risk of type 2 diabetes. J Clin Invest 117:2155-2163

46. Zimdahl H, Ittrich C, Graefe-Mody U et al (2014) Influence of $T C F 7 L 2$ gene variants on the therapeutic response to the dipeptidylpeptidase-4 inhibitor linagliptin. Diabetologia 57: 1869-1875

47. Florez JC, Jablonski KA, Bayley N et al (2006) TCF7L2 polymorphisms and progression to diabetes in the Diabetes Prevention Program. N Engl J Med 355:241-250

48. Wegner L, Hussain MS, Pilgaard K et al (2008) Impact of TCF7L2 rs7903146 on insulin secretion and action in young and elderly Danish twins. Clin Endocrinol Metab 93:4013-4019

49. Alibegovic AC, Sonne MP, Højbjerre L et al (2010) The T-allele of TCF7L2 rs7903146 associates with a reduced compensation of insulin secretion for insulin resistance induced by 9 days of bed rest. Diabetes 59:836-843

50. Daniele G, Gaggini M, Comassi M et al (2015) Glucose metabolism in high-risk subjects for type 2 diabetes carrying the rs7903146 TCF7L2 gene variant. J Clin Endocrinol Metab 100: E1160-E1167

51. Le Bacquer O, Kerr-Conte J, Gargani S et al (2012) TCF7L2 rs7903146 impairs islet function and morphology in nondiabetic individuals. Diabetologia 55:2677-2681

52. Machann J, Thamer C, Stefan N et al (2010) Follow-up wholebody assessment of adipose tissue compartments during a lifestyle intervention in a large cohort at increased risk for type 2 diabetes. Radiology 257:353-363

53. Thamer C, Machann J, Staiger H et al (2010) Interscapular fat is strongly associated with insulin resistance. J Clin Endocrinol Metab 95:4736-4742

54. Rittig K, Staib K, Machann J et al (2008) Perivascular fatty tissue at the brachial artery is linked to insulin resistance but not to local endothelial dysfunction. Diabetologia 51:2093-2099

55. Stefan N, Kantartzis K, Machann J et al (2008) Identification and characterization of metabolically benign obesity in humans. Arch Intern Med 168:1609-1616

56. Kantartzis K, Machann J, Schick F et al (2011) Effects of a lifestyle intervention in metabolically benign and malign obesity. Diabetologia 54:864-868 
57. Stefan N, Häring HU, Hu FB, Schulze MB (2013) Metabolically healthy obesity: epidemiology, mechanisms, and clinical implications. Lancet Diabetes Endocrinol 1:152-162

58. Stefan N, Häring HU (2011) The metabolically benign and malignant fatty liver. Diabetes 60:2011-2017

59. Romeo S, Kozlitina J, Xing C et al (2008) Genetic variation in PNPLA3 confers susceptibility to nonalcoholic fatty liver disease. Nat Genet 40:1461-1465

60. Kantartzis K, Peter A, Machicao F et al (2009) Dissociation between fatty liver and insulin resistance in humans carrying a variant of the patatin-like phospholipase 3 gene. Diabetes 58: 2616-2623

61. Peter A, Kovarova M, Nadalin S et al (2014) PNPLA3 variant I148M is associated with altered hepatic lipid composition in humans. Diabetologia 57:2103-2107

62. Kovarova M, Königsrainer I, Königsrainer A et al (2015) The genetic variant I148M in PNPLA3 is associated with increased hepatic retinyl-palmitate storage in humans. J Clin Endocrinol Metab 100:E1568-E1574

63. Stefan N, Häring HU (2013) The role of hepatokines in metabolism. Nat Rev Endocrinol 9:144-152

64. Stefan N, Häring HU (2013) Circulating fetuin-A and free fatty acids interact to predict insulin resistance in humans. Nat Med 19: 394-395

65. Stefan N, Schick F, Häring HU (2014) Ectopic fat in insulin resistance, dyslipidemia, and cardiometabolic disease. $\mathrm{N}$ Engl $\mathrm{J}$ Med 371:2236-2237

66. Stefan N, Fritsche A, Weikert C et al (2008) Plasma fetuin-A levels and the risk of type 2 diabetes. Diabetes 57:2762-2767

67. Weikert C, Stefan N, Schulze MB et al (2008) Plasma fetuin-a levels and the risk of myocardial infarction and ischemic stroke. Circulation 118:2555-2562

68. Dasgupta S, Bhattacharya S, Biswas A et al (2010) NF-kB mediates lipid-induced fetuin-A expression in hepatocytes that impairs adipocyte function effecting insulin resistance. Biochem J 429:451-462

69. Takata H, Ikeda Y, Suehiro T et al (2009) High glucose induces transactivation of the alpha2-HS glycoprotein gene through the ERK1/2 signaling pathway. J Atheroscler Thromb 16:448-456

70. Lee J, Hong SW, Park SE et al (2015) Exendin-4 inhibits the expression of SEPP1 and fetuin-A via improvement of palmitic acid-induced endoplasmic reticulum stress by AMPK. Endocrinol Metab (Seoul) 2015:177-184

71. Srinivas PR, Wagner AS, Reddy LV et al (1993) Serum alpha 2-HS-glycoprotein is an inhibitor of the human insulin receptor at the tyrosine kinase level. Mol Endocrinol 7:1445-1455

72. Siegel-Axel DI, Ullrich S, Stefan N et al (2014) Fetuin-A influences vascular cell growth and production of proinflammatory and angiogenic proteins by human perivascular fat cells. Diabetologia 57:1057-1066

73. Pal D, Dasgupta S, Kundu R et al (2012) Fetuin-A acts as an endogenous ligand of TLR4 to promote lipid-induced insulin resistance. Nat Med 18:1279-1285

74. Yudkin JS, Eringa E, Stehouwer CD (2005) "Vasocrine" signalling from perivascular fat: a mechanism linking insulin resistance to vascular disease. Lancet 365:1817-1820

75. Meijer RI, Serne EH, Smulders YM, van Hinsbergh VW, Yudkin JS, Eringa EC (2011) Perivascular adipose tissue and its role in type 2 diabetes and cardiovascular disease. Curr Diab Rep 11: 211-217

76. Rittig K, Dolderer JH, Balletshofer B et al (2012) The secretion pattern of perivascular fat cells is different from that of subcutaneous and visceral fat cells. Diabetologia 55:1514-1525

77. Wagner R, Machann J, Lehmann R et al (2012) Exercise-induced albuminuria is associated with perivascular renal sinus fat in individuals at increased risk of type 2 diabetes. Diabetologia 55: 2054-2058

78. Stefan N, Artunc F, Heyne N, Machann J, Schleicher ED, Häring HU (2016) Obesity and renal disease: not all fat is created equal and not all obesity is harmful to the kidneys. Nephrol Dial Transplant 31:726-730

79. Heni M, Machann J, Staiger H et al (2010) Pancreatic fat is negatively associated with insulin secretion in individuals with impaired fasting glucose and/or impaired glucose tolerance: a nuclear magnetic resonance study. Diabetes Metab Res Rev 26: 200-205

80. Stefan N, Sun Q, Fritsche A et al (2014) Impact of the adipokine adiponectin and the hepatokine fetuin-A on the development of type 2 diabetes: prospective cohort- and cross-sectional phenotyping studies. PLoS One 9, e92238

81. Silbernagel G, Kovarova M, Cegan A et al (2012) High hepatic SCD1 activity is associated with low liver fat content in healthy subjects under a lipogenic diet. J Clin Endocrinol Metab 97: E2288-E2292

82. Browning JD, Baker JA, Rogers T, Davis J, Satapati S, Burgess SC (2011) Short-term weight loss and hepatic triglyceride reduction: evidence of a metabolic advantage with dietary carbohydrate restriction. Am J Clin Nutr 93:1048-1052

83. Ryan MC, Abbasi F, Lamendola C, Carter S, McLaughlin T (2007) Serum alanine aminotransferase levels decrease further with carbohydrate than fat restriction in insulin-resistant adults. Diabetes Care 30:1075-1080

84. Utzschneider KM, Bayer-Carter JL, Arbuckle MD, Tidwell JM, Richards TL, Craft S (2013) Beneficial effect of a weight-stable, low fat/ low-saturated fat/low-glycaemic index diet to reduce liver fat in older subjects. Br J Nutr 109:1096-1104

85. Cussons AJ, Watts GF, Mori TA, Stuckey BG (2009) Omega-3 fatty acid supplementation decreases liver fat content in polycystic ovary syndrome: a randomized controlled trial employing proton magnetic resonance spectroscopy. J Clin Endocrinol Metab 94: $3842-3848$

86. Scorletti E, Bhatia L, McCormick KG et al (2014) Effects of purified eicosapentaenoic and docosahexaenoic acids in nonalcoholic fatty liver disease: results from the Welcome study. Hepatology 60:1211-1221

87. Stefan N, Machicao F, Staiger H et al (2005) Polymorphisms in the gene encoding adiponectin receptor 1 are associated with insulin resistance and high liver fat. Diabetologia 48: 2282-2291

88. Thamer C, Machann J, Stefan N et al (2008) Variations in PPARD determine the change in body composition during lifestyle intervention: a whole-body magnetic resonance study. J Clin Endocrinol Metab 93:1497-1500

89. Hawley JA, Hargreaves M, Joyner MJ, Zierath JR (2014) Integrative biology of exercise. Cell 159:738-749

90. Osler ME, Fritz T, Caidahl K et al (2015) Changes in gene expression in responders and nonresponders to a low-intensity walking intervention. Diabetes Care 38:1154-1160

91. Kantartzis K, Thamer C, Peter A et al (2009) High cardiorespiratory fitness is an independent predictor of the reduction in liver fat during a lifestyle intervention in non-alcoholic fatty liver disease. Gut 58:1281-1288

92. Böhm A, Weigert C, Staiger H, Häring HU (2016) Exercise and diabetes: relevance and causes for response variability. Endocrine 51:390-401

93. Stephens NA, Xie H, Johannsen NM, Church TS, Smith SR, Sparks LM (2015) A transcriptional signature of 'exercise resistance' in skeletal muscle of individuals with type 2 diabetes mellitus. Metabolism 64:999-1004 
94. Boulé NG, Weisnagel SJ, Lakka TA et al (2005) Effects of exercise training on glucose homeostasis: the HERITAGE Family Study. Diabetes Care 28:108-114

95. Hoene M, Runge H, Häring HU, Schleicher ED, Weigert C (2013) Interleukin- 6 promotes myogenic differentiation of mouse skeletal muscle cells: role of the STAT3 pathway. Am J Physiol Cell Physiol 304:C128-C136

96. Scheler M, Irmler M, Lehr S et al (2013) Cytokine response of primary human myotubes in an in vitro exercise model. Am J Physiol Cell Physiol 305:C877-C886

97. Hansen JS, Zhao X, Irmler M et al (2015) Type 2 diabetes alters metabolic and transcriptional signatures of glucose and amino acid metabolism during exercise and recovery. Diabetologia 58: 1845-1854

98. Weigert C, Lehmann R, Hartwig S, Lehr S (2014) The secretome of the working human skeletal muscle - a promising opportunity to combat the metabolic disaster? Proteomics Clin Appl 8:5-18

99. Havrankova J, Brownstein M, Roth J (1981) Insulin and insulin receptors in rodent brain. Diabetologia 20(Suppl):268-273

100. Havrankova J, Roth J, Brownstein M (1978) Insulin receptors are widely distributed in the central nervous system of the rat. Nature 272:827-829

101. Brüning JC, Gautam D, Burks DJ et al (2000) Role of brain insulin receptor in control of body weight and reproduction. Science 289: $2122-2125$

102. Okamoto H, Nakae J, Kitamura T, Park BC, Dragatsis I, Accili D (2004) Transgenic rescue of insulin receptor-deficient mice. J Clin Invest 114:214-223

103. Lin X, Taguchi A, Park S et al (2004) Dysregulation of insulin receptor substrate 2 in beta cells and brain causes obesity and diabetes. J Clin Invest 114:908-916

104. Tschritter O, Preissl H, Hennige AM et al (2006) The cerebrocortical response to hyperinsulinemia is reduced in overweight humans: a magnetoencephalographic study. Proc Natl Acad Sci U S A 103:12103-12108

105. Heni M, Kullmann S, Preissl H, Fritsche A, Häring HU (2015) Impaired insulin action in the human brain: causes and metabolic consequences. Nat Rev Endocrinol 11:701-711

106. Kullmann S, Heni M, Veit R et al (2015) Selective insulin resistance in homeostatic and cognitive control brain areas in overweight and obese adults. Diabetes Care 38:1044-1050
107. Heni M, Wagner R, Kullmann S et al (2014) Central insulin administration improves whole-body insulin sensitivity via hypothalamus and parasympathetic outputs in men. Diabetes 63: 4083-4088

108. Guthoff M, Grichisch Y, Canova $C$ et al (2010) Insulin modulates food-related activity in the central nervous system. J Clin Endocrinol Metab 95:748-755

109. Grichisch Y, Çavuşoğlu M, Preissl H et al (2012) Differential effects of intranasal insulin and caffeine on cerebral blood flow. Hum Brain Mapp 33:280-287

110. Heni M, Kullmann S, Ketterer C et al (2012) Nasal insulin changes peripheral insulin sensitivity simultaneously with altered activity in homeostatic and reward-related human brain regions. Diabetologia 55:1773-1782

111. Kullmann S, Frank S, Heni M et al (2013) Intranasal insulin modulates intrinsic reward and prefrontal circuitry of the human brain in lean women. Neuroendocrinology 97:176-182

112. Tschritter O, Preissl H, Hennige AM et al (2012) High cerebral insulin sensitivity is associated with loss of body fat during lifestyle intervention. Diabetologia 55:175-178

113. Scherer T, Lindtner C, O'Hare J et al (2016) Insulin regulates hepatic triglyceride secretion and lipid content via signaling in the brain. Diabetes. doi:10.2337/db15-1552

114. Kleinridders A, Ferris HA, Cai W, Kahn CR (2014) Insulin action in brain regulates systemic metabolism and brain function. Diabetes 63:2232-2243

115. Pocai A, Lam TK, Gutierrez-Juarez R et al (2005) Hypothalamic K(ATP) channels control hepatic glucose production. Nature 434: 1026-1031

116. Obici S, Feng Z, Karkanias G, Baskin DG, Rossetti L (2002) Decreasing hypothalamic insulin receptors causes hyperphagia and insulin resistance in rats. Nat Neurosci 5:566-572

117. Gancheva S, Koliaki C, Bierwagen A et al (2015) Effects of intranasal insulin on hepatic fat accumulation and energy metabolism in humans. Diabetes 64:1966-1975

118. Linder K, Schleger F, Ketterer C et al (2014) Maternal insulin sensitivity is associated with oral glucose-induced changes in fetal brain activity. Diabetologia 57:1192-1198

119. Linder K, Schleger F, Kiefer-Schmidt I et al (2015) Gestational diabetes impairs human fetal postprandial brain activity. J Clin Endocrinol Metab 100:4029-4036 